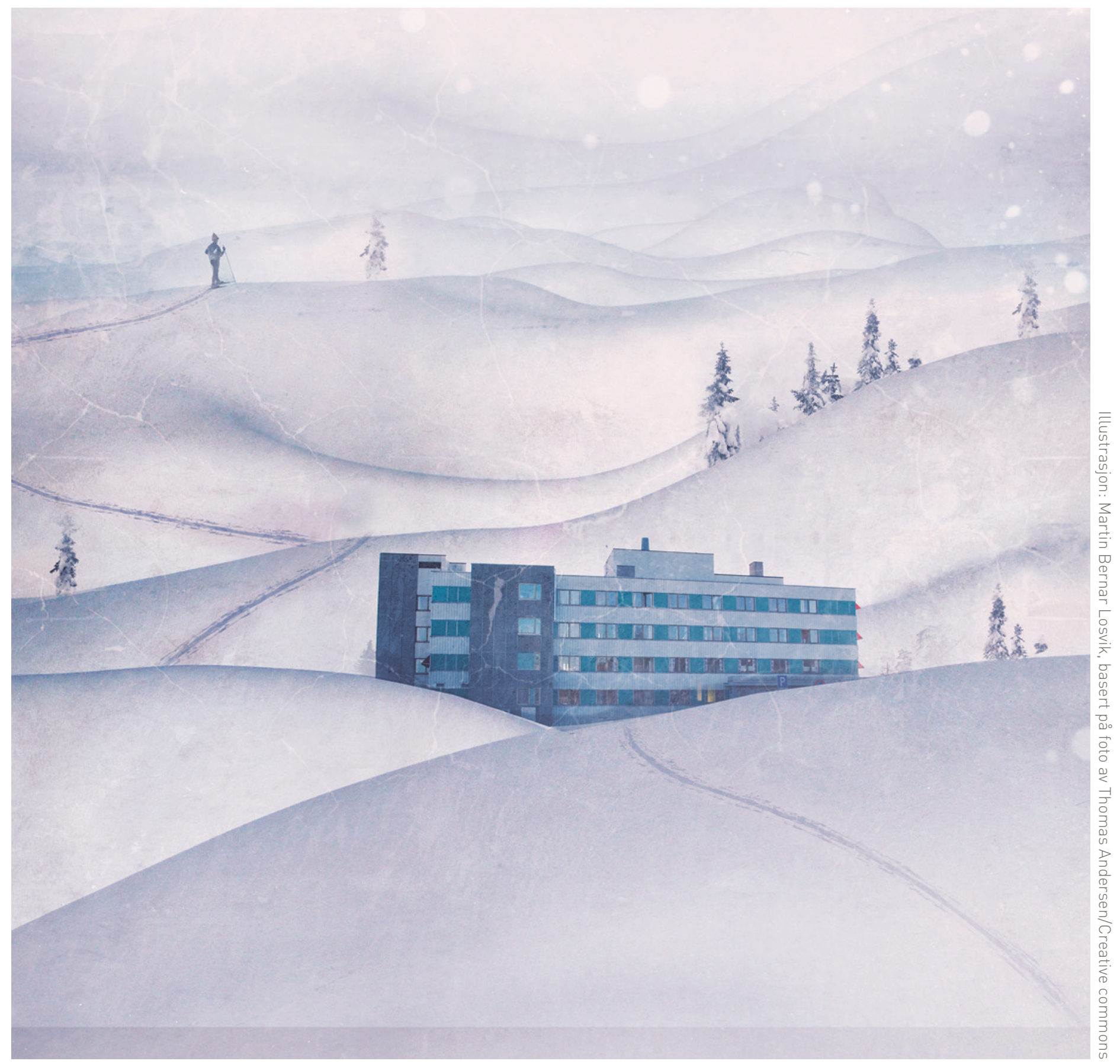

\title{
Sykehuset Innlandet, Hamar
} -1. Skøytebyen er administrasjonssete for Hedmark fylke og har over 26000 innbyggere. Her finnes Vikingog sammen utgjør de én av divisjonene i Sykehuset Innlandet. 